\title{
A Study on the Architectural Planning Guidelines of the Wards in Central Public Hospitals of the Communities
}

\author{
지역거점 공공병원의 병동부 건축계획 기준에 관한 연구 \\ Choi, Kwangseok* 최광석 | Chai, Choul Gyun** 채철균 | Kwon, SoonJung*** 권순정
}

\begin{abstract}
Purpose: This study aims to suggest the architectural planning guidelines for the nurse area and patients' convenient facilities design of the wards in central public hospitals of the communities. Methods: In order to suggest architectural planning guidelines, expert's interview, field survey and analysis of the floor plan have been conducted in this paper. Results: This paper presents room configurations and space program, which determines the areas and structures of the spaces in the wards. Also it suggests the examples of floor plans which contains how to design nurse area and convenient facilities of the patient in the wards. Implications: The result of this research would be useful as a reference when the architect tries to design nurse area and convenient facilities of the patient of the wards.
\end{abstract}

Keywords Public Hospital, The Ward Planning, Nurse Area, Convenient Spaces of the Patient 주 제 어 공공병원, 병동계획, 간호제실, 환자편의시설

\section{Introduction}

\subsection{Research Background and Objective}

병원건축은 전반적으로 기계화, 자동화되어 가고 있지만, 환자가 24시간 거주하는 병동은 인간적인 생활상과 의료진의 활동이 중요하며, 타부문과는 다른 건축계획적인 접근방식이 필요하다. 병동계획의 주된 관심사는 환자의 프라이버시와 간 호를 위한 의료진의 관찰 용이성을 확보하는 것으로 쾌적한 병실 환경을 만들고, 간호의 질과 간호 효율성을 동시에 성취 할 수 있는 구성이 필요하다.

그러나 공공병원은 대부분 건립된 지 오래되어 낙후된 이 미지를 벗어나지 못하고 있는 상태로서, 이미지 개선과 시설 의 현대화 계획이 요구되고 있다(채철균 외, 2013;41). 예를

* Director, Ph.D. Vice President of Heerim Architects \& Planners (Primary \& Corresponding author: daumchois@hanmail.net)

** Director, Professor, Dr.-Ing. Department of Architecture, Kwangwoon University (chai@kw.ac.kr)

*** Vice President, Professor, Ph.D. Department of Architecture, Ajou University (sjkwon@ajou.ac.kr)

본 논문은 지역거점 공공병원 병동부 건축계획 기준개발을 위하

여 진행한 연구결과 및 보고서(보건복지부, 한국의료복지건축학

회: 2013)를 토대로 작성되었다.
들어, 병원의 상당수가 5 인 이상의 다인 병실로 운영되고 있 어, 병실 내 환자의 개인공간이 확보되지 못하고, 협소하며, 보호자, 간병인 등 체류인원이 과다하여 혼잡과 감염의 위험 에 노출되는 등 환자 민원이 많이 발생하고 있는 실정이다.

이러한 점을 개선하기 위하여 공공병원은 기준 병실을 4 인 실로 전환하여 환자의 거주성을 높이고 환자 편의공간을 확 충함으로서 국민들의 의료 요구변화에 적극적으로 대응하려 는 움직임이 나타나고 있다.

본 연구에서는 공공병원 병동부를 대상으로 환자와 보호자 를 위한 편의시설과 의료진을 위한 간호제실에 대하여 환자 와 간호사 입장을 반영한 건축계획 기준을 제시하고자 한다.

\subsection{Research Methods}

본 연구는 병동 관련 문헌조사를 포함하여 전국에 분포한 39 개 공공병원(34개 공공의료원 +5 개 적십자병원)을 대상으 로 설문조사와 현장조사를 병행하였으며, 연구기간은 2013년 2월 15일부터 5월 14일까지이다.

1) 문헌조사 : 병동 관련 국내외 건축계획 기준과 관련 이론 을 분석하였으며, 이를 토대로 설문 및 방문조사를 위해 구조 화된 설문지 및 현장조사를 위한 체크리스트를 작성하였다. 
2) 도면조사 : 39개 공공병원을 대상으로 도면자료를 요청 하여 전체 시설도면 수집이 가능하였던 12개 병원(수원, 파주, 김천, 제주, 남원, 안동, 부산, 청주, 군산, 포천, 포항, 안성의료 원)을 대상으로 공간구성 현황을 분석하였으며, 면적분석을 위해 8개 민간병원(중앙대, 전남대화순, 고대구로, 아주대, 강 남성모, 양산부산대, 건국대, 고대구로병원)의 도면을 분석하 였다.

3) 설문조사 : 39 개 공공병원을 대상으로 각각 환자 설문 (20부), 간호사 설문(1부)을 실시하여 회신된 27개 병원(본문 참조)에 대하여, 병실의 현황 및 개선방향에 대한 자료를 수집 하고 이를 분석하여 환자와 간호사의 입장에서 보는 병동 공 간의 개선안을 도출하도록 하였다.

4) 현장조사 : 9 개 공공병원을 방문하여, 설문내용을 확인 하고, 시설현황을 파악하였으며, 환자와 간호사 면담을 통해 시설과 사용자 현황을 분석하였다(2013년 4월17 24일).

연구의 범위는 병동부의 표준병동을 대상으로 하고 있으 며, 현재 5 6인실이 일반적인 공공병원의 기준 병실을 4인실 로 조정하는 방안을 전제로 이루어진 것이다.

\section{Floor Plan Types and Area Compositions}

\section{2-1 Types and Spaces}

병원은 사용자인 환자를 위하여 존재하는 시설이다. 우리 나라에서는 오래전부터 의료에 대한 환자들의 권리 의식이 개선되고 병원환경에 대한 관심도 높아져서 병원건축에서 환 자의 요구에 부응하고 환자의 건강을 지원하는 환자중심과 치유환경에 대한 개념이 중요한 계획요소가 되고 있다.

\section{1) 평면유형}

병동의 평면유형은 의학적 요구와 사회적인 변화를 수용하 기 위해 변화, 발전되어 왔는데, 특히 동선과 관련된 기능적인 효율성을 개선하는 방향으로 이루어져 왔다. 동선은 병동의 건축계획 요소인 환자의 프라이버시, 관찰성, 그리고 경제성 에 중요한 영향을 미치는 요소이다. 따라서 병동의 평면유형 은 동선 즉 복도형태에 따라 분류하는 것이 보편적인 방식이 다. 가장 기본적인 분류로서 편복도형, 중복도형, 이중복도형, 순환형(사각형, 삼각형, 원형 등)이 있다.

\section{2) 공간의 구성 및 분류}

병동부 병동의 공간은 크게 환자 전용 공간, 환자 편의 공 간, 간호부속 공간, 교육연구 공간, 서비스 공간, 공용 공간 등 으로 구분된다. 이때 환자 전용 공간과 환자 편의 공간은 환자 공간으로, 간호부속 공간, 교육연수 공간, 서비스 공간은 직원 공간으로 구성된다.
[표 1] 병동의 공간 분류표

\begin{tabular}{|c|c|c|c|c|}
\hline \multicolumn{4}{|c|}{ 기능 } & 관련 실 \\
\hline \multirow{11}{*}{ 병동 } & \multirow{2}{*}{$\begin{array}{l}\text { 환자 } \\
\text { 공간 }\end{array}$} & \multicolumn{2}{|c|}{ 환자전용공간 } & 병실, 병실내 화장실 \\
\hline & & \multicolumn{2}{|c|}{ 환자편의공간 } & $\begin{array}{l}\text { 데이룸, 공용화장실, 장애인화장실, } \\
\text { 화자욕실, 좌욕실 }\end{array}$ \\
\hline & \multirow{8}{*}{$\begin{array}{l}\text { 직원 } \\
\text { 공간 }\end{array}$} & \multirow{6}{*}{$\begin{array}{l}\text { 간호 } \\
\text { 부속 } \\
\text { 공간 }\end{array}$} & 간호근무 & 간호근무실(NS), 널스 코너(NC) \\
\hline & & & 진료/치료 & 치료 및 처치실, 준비실/작업실 \\
\hline & & & 진료지원 & $\begin{array}{l}\text { 청결물/소독물실, 린넨실, } \\
\text { 오물처리실, 폐기물처리실, 창고 }\end{array}$ \\
\hline & & & 간호지원 & 수간호사실, 창고 \\
\hline & & & 간호생활 & $\begin{array}{l}\text { 간호사실/간호사휴게실, } \\
\text { 간호사갱의실, 간호사 화장실 }\end{array}$ \\
\hline & & & 기타공간 & $\begin{array}{l}\text { 당직실, 직원화장실, } \\
\text { 스트레처/휠체어보관실 }\end{array}$ \\
\hline & & \multicolumn{2}{|c|}{ 교육연구공간 } & $\begin{array}{l}\text { 의사실, 교수실, 전공의실, } \\
\text { 전임의실, 의국, 사무실, } \\
\text { 회의실, 자료보관실, 교육실 }\end{array}$ \\
\hline & & \multicolumn{2}{|c|}{ 서비스공간 } & 배선실, 용역원실, 청소도구실 \\
\hline & $\begin{array}{l}\text { 공용 } \\
\text { 공간 }\end{array}$ & \multicolumn{2}{|c|}{ 공용공간 } & 복도, 승강기, 계단실, 덕트 \\
\hline
\end{tabular}

3) 면적산정 기준

병동의 면적산정 방식은 우리나라와 외국이 다르고 국내에 서도 연구자 별로 다르다. 따라서 연구에 앞서 산정기준에 대 한 설정과 정의가 필요한데, 순면적과 공용면적의 산정은 전 술한 병동의 공간분류와 같은 맥락으로 복도와 설비공간을 공용공간으로 분류한 국제기준 ISO9836에 따르면 된다.

[표 2] 면적관련 국제기준 ISO 9836(1992)

\begin{tabular}{|c|c|c|c|c|c|}
\hline \multicolumn{4}{|c|}{ 면적구성 } & 사례 & 비고 \\
\hline \multirow{6}{*}{$\begin{array}{c}\text { 총바닥 } \\
\text { 면적 }\end{array}$} & \multirow{4}{*}{$\begin{array}{l}\text { 순바닥 } \\
\text { 면적 }\end{array}$} & \multirow{2}{*}{$\begin{array}{l}\text { 사용 } \\
\text { 가능 } \\
\text { 면적 }\end{array}$} & $\begin{array}{c}\text { 주기능 } \\
\text { 면적 }\end{array}$ & $\begin{array}{l}\text { 병실, 진찰실, } \\
\text { 방사선촬영실, } \\
\text { 검사실 등 }\end{array}$ & \multirow[t]{2}{*}{ 순면적 } \\
\hline & & & $\begin{array}{c}\text { 보조기능 } \\
\text { 면적 }\end{array}$ & $\begin{array}{l}\text { 창고, 청소도구실, } \\
\text { 준비실 등 }\end{array}$ & \\
\hline & & \multicolumn{2}{|c|}{ 동선 면적 } & 계단, 복도, 램프 & \multirow[b]{2}{*}{ 공용면적 } \\
\hline & & \multicolumn{2}{|c|}{ 설비 면적 } & $\begin{array}{l}\text { HVAC, 기계실, } \\
\text { 전기실 }\end{array}$ & \\
\hline & \multirow{2}{*}{\multicolumn{3}{|c|}{ 구조체 면적 }} & 내벽 & \\
\hline & & & & 외벽 & \\
\hline
\end{tabular}

이 방식의 한 가지 문제점은 구조체의 면적이다. 우리나라 는 순면적의 기준을 벽체 중심선으로 하고 있기 때문에 벽체 안목치수를 순면적의 산정기준으로 하고 있는 제 외국의 기 준과 차이가 생긴다. 기능적으로 안목치수를 순면적의 기준으 
로 보는 것이 타당하지만, 그동안 벽체 중심선을 면적산정기 준으로 적용해온 국내의 관행도 무시할 수 없으므로 본 연구 에서는 벽체중심선을 기준으로 면적 산정하는 것을 원칙으로 한다.

\section{2-2 Floor Plan Types and Area Compositions}

1) 공공병원의 평면유형

- 공공병원은 편복도형, 중복도형, 이중복도형으로 평면유 형이 구성되어 있다.

- 예외로 안동의료원 증축 부분이 순환형의 형태이다.

- 주로 경제적인 중복도의 형태이나 최근 개축된 병원에서 이중복도형과 편복도형이 보이고 있어 환자의 쾌적성과 간호 효율성을 고려한 계획이 이루어지고 있다.

- 증축의 형태는 대부분 기존 시설의 연장으로 평면유형의 개선이 어려웠으나, 이전 신축의 경우는 최신 유행의 평면유 형을 채택할 수 있었다.

- 공공병원의 간호운영방식이 팀간호 방식으로 전환되고 있으므로 이를 고려한 평면유형의 모델 개발이 필요하다.

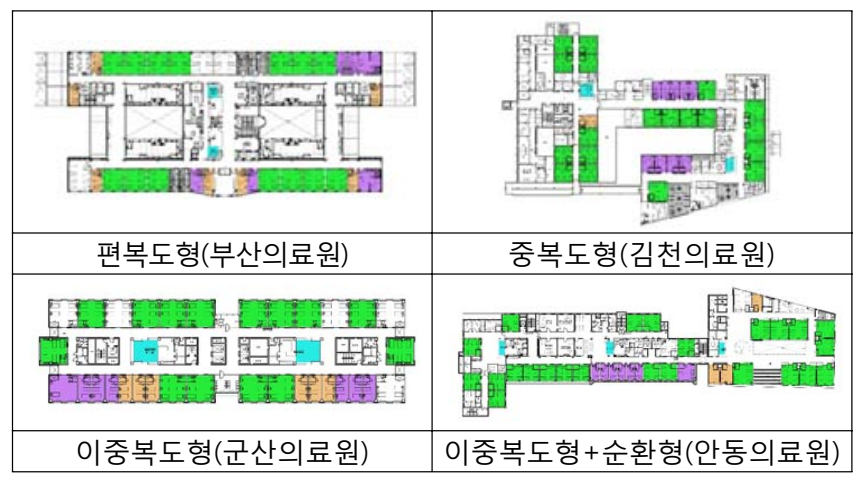

[그림 1] 공공병원 평면유형 사례

2) 면적구성

(1) 공간 영역별 구성 비율

- 총 19 개 병원(공공병원 11 개, 민간병원 8 개)의 면적을 분 석하였다.

- 공공병원 대 민간병원의 면적구성비는 병실 $45 \%: 40 \%$, 간호공간 $10 \%: 13 \%$, 공용공간 $32 \%: 36 \%$ 로 공공병원은 병 실의 면적비율이 높은 반면, 민간병원은 간호공간과 공용공간 의 비율이 높다.

- 공공병원 병실공간의 면적구성비가 민간병원보다 높은 이유는 상대적인 면적이 큰 것이 아니라 간호공간과 공용공 간의 절대면적이 작기 때문에 비율이 높아진 것이다.

(2) 병상당 면적

- 1 개 병동의 병상당 면적은 공공병원 $20 \mathrm{~m}^{2}$, 민간병원 $25 \mathrm{~m}^{2}$ 정도이다.
- 영역별 공공병원 대 민간병원의 병상당 면적은 환자공간 $10.6 \mathrm{~m}^{2}: 11.4 \mathrm{~m}^{2}$, 직원공간 $2.7 \mathrm{~m}^{2}: 3.9 \mathrm{~m}^{2}$, 공용공간 $6.9 \mathrm{~m}^{2}: 9.4$ $\mathrm{m}^{2}$ 로 모든 공간에서 공공병원보다 민간병원이 높다.

- 환자 공간, 특히 병실공간보다는 직원공간과 공용공간의 면적 차이가 있다. 이것은 공공병원이나 민간병원 모두 기본 공간인 병실공간의 면적수준은 차이가 적지만, 그 이외의 공 간에서 차이가 있다는 것을 알 수 있다.

\section{The Number of Beds in Nursing Unit}

\section{3-1 Nursing Staffs and Nursing Methods}

1) 간호인력(이상윤 외,2008;10 11 요약)

- OECD 국가 평균 근무시간 중 간호사 1 인당 담당 병상수 는 4 5병상 수준이다.

- 2008년 미국 캘리포니아주 급성기병원의 간호사 1 인당 환자수 기준은 내과계/외과계 병동 6 명, 소아과 병동 4 명, 정 신과 병동 6 명, 중환자실 2 명이다.

- 한국 간호사는 $\mathrm{OECD}$ 국가 평균에 비해 3 6배 많은 병상 을 담당하고 있어 질적인 문제뿐만 아니라 인력구조의 양적 확충이 절대적으로 필요한 실정이다.

2) 간호방식

- 팀 간호 방식과 기능간호방식이 혼용되고 있다.

- 팀 간호 방식이 기능간호방식을 사용하는 병원보다 간호 사 1 인당 환자수가 적은 경향을 보이고 있으며, 간호사 1 인당 담당 병상은 18 20병상이다. 그러나 20병상을 크게 넘어서는 병원(B병원)도 있다.

[표 3] 국내 병원의 간호방식 및 간호사 1 인당 병상수 (이상윤 외,2008;17 18 재편집)

\begin{tabular}{|c|c|c|c|c|c|c|c|c|c|c|c|c|c|}
\hline \multirow[b]{2}{*}{ 병원 } & \multirow[b]{2}{*}{$\begin{array}{l}\text { 병상 } \\
\text { 수 }\end{array}$} & \multirow[b]{2}{*}{ 종별 } & \multirow[b]{2}{*}{ 설리병 } & \multirow[b]{2}{*}{$\begin{array}{l}\text { 가동 } \\
\text { 병상 }\end{array}$} & \multirow[b]{2}{*}{$\begin{array}{c}\text { 병상 } \\
\text { 이용 } \\
\text { 율 }\end{array}$} & \multirow[b]{2}{*}{ 간홍급 } & \multicolumn{2}{|c|}{ Day } & \multicolumn{2}{|c|}{ Evening } & \multicolumn{2}{|c|}{ Night } & \multirow[b]{2}{*}{$\begin{array}{l}\text { 간호 } \\
\text { 방식 }\end{array}$} \\
\hline & & & & & & & 간호 & $\begin{array}{l}\text { 병상 } \\
\text { 수/1 } \\
\text { 인 }\end{array}$ & 간호 & $\begin{array}{l}\text { 병상 } \\
\text { 수/1 } \\
\text { 인 }\end{array}$ & 간호수 & $\begin{array}{l}\text { 병상 } \\
\text { 수/1 } \\
\text { 인 }\end{array}$ & \\
\hline A & 36 & \multirow{4}{*}{$\begin{array}{l}\text { 송합 } \\
\text { 욘향 } \\
\text { 병원 }\end{array}$} & 특수 & 1633 & 90.9 & 2 & 2.51) & 14.4 & 2.5 & 14.4 & 2 & 18 & 팀 \\
\hline B & 72 & & 학교 & 916 & 87.4 & 4 & 3 & 24 & 3 & 24 & 2 & 36 & 팀 \\
\hline C & 36 & & 특수 & 878 & 90.1 & 3 & 2 & 18 & 2 & 18 & 2 & 18 & - \\
\hline D & 47 & & 특수 & 663 & 85.0 & 4 & 2 & 23.5 & 2 & 23.5 & 2 & 23.5 & - \\
\hline$E$ & 62 & \multirow{3}{*}{$\begin{array}{l}\text { 종합 } \\
\text { 병원 }\end{array}$} & 재단 & 780 & 93.4 & 3 & 4 & 15.5 & 3 & 20.7 & 3 & 20.7 & 팀 \\
\hline $\mathrm{F}$ & 67 & & 의료 & 661 & & 5 & 3 & 22.3 & 3 & 22.3 & 3 & 22.3 & 기능 \\
\hline $\mathrm{H}$ & 51 & & 특수 & 256 & 83.0 & 4 & 2 & 25.5 & 2 & 25.5 & 2 & 25.5 & $\begin{array}{l}\text { 팀+ } \\
\text { 기능 }\end{array}$ \\
\hline
\end{tabular}

3) 간호등급별 간호단위당 병상수

- 팀 간호 방식에서 팀당 환자수 한계를 15 20병상으로 볼 때, 간호단위의 병상수는 간호사 3 인 근무기준 45 60병상이

1) Day와 Evening에 걸쳐 일하는 PRN 간호사 1 인을 0.5 인으로 계산 
다. 즉, 팀 간호를 도입하려면, 최소한 간호등급이 3 4등급은 되어야 한다.

- 많은 공공병원에서 목표로 하고 있는 간호3등급을 고려 하면, 간호단위당 병상수는 45 50병상이다.

[표 4] 국내병원의 간호등급별 간호단위당 예상 병상수

\begin{tabular}{|c|c|c|c|}
\hline $\begin{array}{l}\text { 간호 } \\
\text { 등급 }\end{array}$ & $\begin{array}{c}\text { 등급기준 } 2) \\
\text { (총병상 대 간호사) }\end{array}$ & $\begin{array}{c}\text { 병동기준 } \\
\text { 간호사 } 1 \text { 인당 병상수3) }\end{array}$ & $\begin{array}{c}\text { 간호단위당 병상수 } \\
\text { (Day, Evening RN 3인 기준) }\end{array}$ \\
\hline 1 등급 & 2.5대 1 미만 & 12.5병상 미만 & 37.5병상 이하 \\
\hline 2 등급 & 3.0대 1 2.5대 1 & 12.5병상 15.0병상 미만 & 37.5병상 45.0병상 미만 \\
\hline 3등급 & 3.5대 1 3.0대 1 & 15.0병상 17.5병상 미만 & 45.0병상 52.5병상 미만 \\
\hline 4등급 & 4.0 대 1 3.5대 1 & 17.5병상 20.0병상 미만 & 52.5병상 60.0병상 미만 \\
\hline 5 등급 & 4.5 대 $1 \sim 4.0$ 대 1 & 20.0병상 22.5병상 미만 & 60.0병상 67.5병상 미만 \\
\hline 6등급 & 6.0대 1 4.5대 1 & 22.5병상 30.0병상 미만 & 67.5병상 90.0병상 미만 \\
\hline 7등급 & 6.0대 1 이상 & 30.0병상 이상 & 90.0병상 이상 \\
\hline
\end{tabular}

주) 간호단위당 병상수 $=$ 병동기준 간호사 1 인당 병상수 $\times 3$ 인

\section{3-2 The Number of Nursing Staffs and Beds of the Wards in Public Hospitals}

1) 간호인력 구성 현황

- 공공병원의 간호등급은 5 7등급의 병원이 많고, 기능간 호방식을 채택한 병원이 대다수이지만, 현재 팀 간호로 전환 하는 것이 큰 흐름이며, 서비스의 질적 향상을 위해 팀 간호 전환은 필수적이다.

[표 5] 공공병원의 간호인력구성 현황

\begin{tabular}{|c|c|c|c|c|c|c|c|c|c|}
\hline 병원 & $\begin{array}{l}\text { 병동 } \\
\text { 유형 }\end{array}$ & $\begin{array}{l}\text { 병상 } \\
\text { 수 }\end{array}$ & 갑홍식 & Day & $\begin{array}{l}\text { Even } \\
\text { ing }\end{array}$ & Night & 간호계 & 총계 & $\begin{array}{l}\text { 간호ㅅㅏㅏ } \\
\text { 1잉당숭ㅅ }\end{array}$ \\
\hline 서울의료원 & 외과 & 50 & 팀 & 3 & 3 & 3 & 15 & 16 & $16 \sim 17$ \\
\hline 인천의료원 & 외과 & 50 & 기능 & 2 & 2 & 2 & 8 & 10 & 25 \\
\hline 수원의료원 & 내과 & 46 & 기능 & 3 & 2 & 2 & 11 & 13 & 23 \\
\hline 의정부의료원 & 내과 & 40 & 기능 & 2 & 2 & 2 & 6 & 7 & 20 \\
\hline 상주적십자 & 외과 & 63 & 기능 & 3 & 3 & 2 & 10 & 12 & 21 \\
\hline 파주의료원 & 내과 & 60 & 기능 & 3 & 4 & 2 & 13 & 15 & 20 \\
\hline 김천의료원 & 외과 & 69 & 기능 & 3 & 3 & 3 & 12 & 15 & 23 \\
\hline 천안의료원 & 외과 & 60 & 기능 & 2 & 3 & 2 & 9 & 11 & 30 \\
\hline 홍성의료원 & 외과 & 75 & 기타 & 4 & 4 & 3 & 13 & 15 & $18 \sim 19$ \\
\hline 제주의료원 & 내과 & 55 & 기능 & 2 & 2 & 2 & 9 & 11 & $27 \sim 28$ \\
\hline 목포의료원 & 내과 & 69 & 기능 & 4 & 3 & 2 & 11 & 12 & 23 \\
\hline 남원의료원 & 내과 & 46 & 기능 & 2 & 1 & 1 & 6 & 8 & 46 \\
\hline 안동의료원 & 외과 & 55 & 기능 & 3 & 2 & 2 & 9 & 11 & $27 \sim 28$ \\
\hline 서울의료원 & 내과 & 57 & 기능 & 3 & 3 & 2 & 13 & 16 & 19 \\
\hline 서귀포의료원 & 내과 & 50 & 기능 & 3 & 3 & 2 & 12 & 14 & $16 \sim 17$ \\
\hline
\end{tabular}

2) 보건복지부 기준

3) 3 교대 업무를 고려한 근무조별 간호사 1 인당 병상수를 계산할 때 에는 일반적으로 4.3 4.4배를 하고 있으나, 실제로 일반병동 간 호사 수에 환자 간호 업무를 덜 하거나 하지 않는 주임 간호사, 수간호사, PA 간호사 수 등이 포함되어 있는 것을 감안하여 5 배 하였음(이상윤 외, 2008;10).

\begin{tabular}{c|c|c|c|c|c|c|c|c|c}
\hline 병원 & $\begin{array}{c}\text { 병동 } \\
\text { 융 }\end{array}$ & $\begin{array}{c}\text { 병상 } \\
\text { 수 }\end{array}$ & $\begin{array}{c}\text { 갑홍 } \\
\text { 식 }\end{array}$ & Day & $\begin{array}{c}\text { Even } \\
\text { ing }\end{array}$ & Night & 간호계 & 총계 & $\begin{array}{c}\text { 간호사 } \\
\text { 빈당 } \\
\text { 방상수 }\end{array}$ \\
\hline 부산의료원 & 외과 & 57 & 팀 & 3 & 2 & 2 & 13 & 14 & $28 ~ 29$ \\
\hline 청주의료원 & 내과 & 66 & 팀 & 4 & 5 & 3 & 17 & 19 & 17 \\
\hline 군산의료원 & 내과 & 55 & 기능 & 4 & 3 & 2 & 12 & 13 & $18 ~ 19$ \\
\hline 강릉의료원 & 내/외 & 118 & 팀 & 3 & 3 & 3 & 15 & 16 & $39 ~ 40$ \\
\hline 포항의료원 & 외과 & 44 & 기능 & - & - & - & 9 & 10 & 22 \\
\hline 안성의료원 & 내과 & 68 & 기능 & 4 & 3 & 3 & 15 & 16 & 23 \\
\hline 대구의료원 & 내과 & 51 & 기능 & 3 & 3 & 2 & 11 & 13 & 17 \\
\hline 순천의료원 & 외과 & 56 & 기타 & 2 & 2 & 2 & 9 & & 28 \\
\hline 삼척의료원 & 외과 & 54 & 기능 & 2 & 2 & 2 & 10 & 11 & 27 \\
\hline 속초의료원 & 외과 & 58 & 기능 & 2 & 2 & 2 & 8 & 9 & 29 \\
\hline 울진의료원 & 내과 & 40 & 팀 & 2 & 2 & 2 & 9 & 11 & 20 \\
\hline 충주의료원 & 내과 & 49 & 기능 & 3 & 3 & 2 & 11 & 14 & 17 \\
\hline
\end{tabular}

- 현재 팀 간호 방식은 간호3등급 정도의 공공병원에서 이 미 시행중이며, 그 이하의 등급에서도 팀 간호 방식을 도입하 려고 하고 있으나 인력문제로 전환을 보류하고 있는 병원이 많은 실정이다.

2) 간호방식과 병상수 기준 설정

기본적으로 공공병원의 간호 인력은 매우 열악한 수준으로 인력확충이 필요하지만, 당장 개선이 어려우므로 다음과 같은 방향을 설정한다.

- 현실적으로 팀 간호가 인력이 더 필요한 것은 사실이지 만, 근본적으로 간호업무의 절대량 대비 팀 간호와 기능간호 방식 모두 간호사 1 인당 환자 수 개념은 같은 것으로 보아야 하고, 그 적정 기준을 초과할 경우, 환자의 치료뿐만 아니라 간호사의 업무만족도 면에서 부정적이 된다. 따라서 적은 간 호사로 많은 환자를 보는 것이나 기능간호가 인력대비 효율 적이라는 의견은 필연적으로 마땅히 제공되어야 할 간호서비 스의 부분적인 누락 또는 전체적인 간호 서비스의 질적 저하 를 전제한 것으로 바람직하지 않으며, 수정되고 교정되어질 필요가 있다.

- 공공병원이 처한 여러 가지 현실을 고려할 때, 다음과 같 은 접근방식이 필요하다.

(1) 간호3 4등급

- 팀 간호 방식 (3교대, Day, Evening 3명 근무 기준)

- 간호사 1인당 15 20명 간호단위당 45 60병상; 이 기준 도 외국에 비해 매우 많은 병상이므로 가능한 간호3등급 45 50병상 구간이 권장된다.

(2) 4 등급 미만의 병원

- 팀 간호를 채택하는 경우, 현재 일부병원에서 시행하고 있는 과도한 병상(간호사당 20 병상 이상)에 대한 팀 간호는 의미가 없으며, 대안으로 간호단위당 병상수를 조정하여 작은 병상수의 단위(직접 간호도가 높은 환자그룹으로서, 예를 들 어 40병상)는 적은 인력(예를 들어 Day, Evening 2명 근무 등) 으로도 팀 간호가 가능하도록 하고, 많은 단위(직접 간호도가 
낮은 환자 그룹)는 잠정적으로 기존의 기능간호방식을 유지 하여, 일정기간 팀 간호와 기능간호를 혼용하는 과도기를 유 지한다.

- 간호방식은 기본적으로 팀 간호 방식으로 설정하고, 인력 문제에 대응하여 어떻게 운영할 것인가 하는 접근방법을 모 색한다.

\section{3-3 Composition of Patient Rooms}

- 공공병원의 병실구성은 5 인실, 6 인실 위주로 구성되어 있 으며, 1, 2인실 2 4실 정도의 구성이다.

- 그러나 장기적으로 입원수요가 감소추세이므로 향후 병 동당 병상 수 감소를 고려하여야 한다.

- 또한 기존 공공병원 병동부의 5,6 인실을 4 인 병실로 변 경할 경우, 현재 인력 대비 병상수가 감소되어 팀 간호 방식의 도입이 유리해진다.

[표 6] 공공병원의 병실구성과 4인병실 전환시, 병상수 변화

\begin{tabular}{|c|c|c|c|c|c|c|c|c|c|c|c|c|c|}
\hline \multirow{2}{*}{ 병원 } & \multirow{2}{*}{ 병도영 } & \multirow{2}{*}{ 갑홍식 } & \multirow{2}{*}{$\begin{array}{l}\text { 병상 } \\
\text { 수 }\end{array}$} & \multicolumn{9}{|c|}{ 병실구성 } & \multirow{2}{*}{$\begin{array}{l}\text { 다일실을롤경신, } \\
\text { 병상수 }\end{array}$} \\
\hline & & & & & 2인 & 3인 & 4 인 & 5인 & 6인 & 7인 & 8 인 & 1 기타 & \\
\hline 서울의료원 & 외과 & 팀 & 50 & 1 & 2 & & & 9 & & & & & 41 \\
\hline 서울의료원 & 내과 & 기능 & 57 & & 2 & & & 1 & 8 & & & & 40 \\
\hline 인천의료원 & 외과 & 기능 & 50 & 3 & 1 & & & 9 & & & & & 41 \\
\hline 수원의료원 & 내과 & 기능 & 46 & 3 & 5 & 1 & & & 5 & & & & 36 \\
\hline 의정부의료원 & 내과 & 기능 & 40 & 1 & & & & 7 & & & & 2 & 33 \\
\hline 상주적십자 & 외과 & 기능 & 63 & & 4 & & & 9 & & & & 1 & 54 \\
\hline 파주의료원 & 내과 & 기능 & 60 & 5 & & & & 17 & & & & & 73 \\
\hline 김천의료원 & 외과 & 기능 & 69 & 9 & & & & 12 & & & & & 57 \\
\hline 천안의료원 & 외과 & 기능 & 60 & 2 & 2 & & 1 & 9 & & & & 5 & 51 \\
\hline 홍성의료원 & 외과 & 기타 & 75 & 1 & 3 & & 2 & 12 & & & & & 63 \\
\hline 제주의료원 & 내과 & 기능 & 55 & 1 & & & & & 4 & & & 3 & 47 \\
\hline 목포의료원 & 내과 & 기능 & 69 & 1 & 1 & & & 2 & 7 & 2 & & & 53 \\
\hline 남원의료원 & 내과 & 기능 & 46 & 7 & & & 1 & 7 & & & & & 39 \\
\hline 안동의료원 & 외과 & 기능 & 55 & 1 & 2 & & & 10 & & & & & 45 \\
\hline 서귀포의료원 & 내과 & 기능 & 50 & & & & & & & & & 5 & \\
\hline 부산의료원 & 외과 & 팀 & 57 & 2 & 4 & & 1 & & 7 & & & 1 & 43 \\
\hline 청주의료원 & 내과 & 팀 & 66 & 8 & & 2 & & 2 & & 6 & & & 64 \\
\hline 군산의료원 & 내과 & 기능 & 55 & 4 & 3 & & 1 & 8 & & & & 1 & 47 \\
\hline 강릉의료원 & 내/외 & 팀 & 118 & 2 & 2 & & & 20 & 2 & & & & 94 \\
\hline 포천의료원 & 외과 & 기능 & 51 & 2 & 1 & & 2 & 2 & & 1 & 2 & & 43 \\
\hline 포항의료원 & 외과 & 기능 & 44 & 2 & & & & & 7 & & & & 30 \\
\hline 안성의료원 & 내과 & 기능 & 68 & 2 & & & 2 & 2 & 8 & & & & 50 \\
\hline 대구의료원 & 내과 & 기능 & 51 & 2 & & & & 3 & 1 & 4 & & & 46 \\
\hline 순천의료원 & 외과 & 기타 & 56 & & 2 & 1 & 1 & 9 & & & & & 47 \\
\hline 삼척의료원 & 외과 & 기능 & 54 & & & & & & 9 & & & & 36 \\
\hline 속초의료원 & 외과 & 기능 & 58 & 4 & 2 & & & 10 & & & & & 48 \\
\hline 울진의료원 & 내과 & 팀 & 40 & 4 & 1 & & & 2 & 4 & & & & 30 \\
\hline 충주의료원 & 내과 & 기능 & 49 & 2 & 4 & & 1 & 7 & & & & & 42 \\
\hline
\end{tabular}

\section{Spacial Composition of the Wards}

\section{4-1 Nurse Area}

1) 간호공간의 설치율과 설치 요구율

(1) 간호공간의 설치율

- 간호휴게실은 설치율이 낮은데, 간호사 갱의실과 통합운 영이 가능하다.

- 회의실, 의사실, 당직실, 의국의 설치율이 낮다. 주로 교육 연구시설로 중앙화 또는 병동별 분산의 병원 운영방침에 따 라야 한다. 단, 당직실은 병동 배치가 필요하다.

- 장비보관과 일반창고는 주요 공간에 밀려 고려대상에서 누락되는 경우가 많은데, 반드시 확보해야 한다.

(2) 간호공간 설치 요구율

- 현재 병원의 설치율과 간호사의 요구율 간의 차이가 큰 항목 중에서 장비창고와 일반창고의 설치가 매우 중요하며, 팀 간호 방식에서는 팀 회의가 매우 중요하므로 교육연구시 설로서가 아니라 간호작업공간으로서 팀 회의실의 공간 확보 가 필요하다.

- 간호작업실의 요구율은 설치율보다 떨어지는데, 이것은 보통 청결물품실과 공용으로 사용가능하다.

\section{[표 7] 간호공간 설치 현황}

\begin{tabular}{|c|c|c|c|c|c|c|c|c|c|c|c|c|c|c|c|}
\hline 구분 & $\begin{array}{l}\text { 간호 } \\
\text { 사실 }\end{array}$ & $\begin{array}{l}\text { 간호 } \\
\text { 유게 }\end{array}$ & $\begin{array}{l}\text { 간호 } \\
\text { 갱의 } \\
\end{array}$ & $\begin{array}{l}\text { 수간 } \\
\text { 호사 } \\
\end{array}$ & $\begin{array}{l}\text { 간호 } \\
\text { 작업 }\end{array}$ & $\begin{array}{l}\text { 처지 } \\
\text { 실 }\end{array}$ & 정경물 & $\begin{array}{l}\text { 울물 } \\
\text { 처리 }\end{array}$ & 린 넨 & 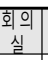 & 의 사 & 당직 & 의국 & \begin{tabular}{|l} 
장바 \\
보관
\end{tabular} & $\begin{array}{l}\text { 일반 } \\
\text { 장 } 1\end{array}$ \\
\hline 서울의료원 & 0 & & 0 & 0 & & 0 & 0 & 0 & 0 & 0 & & 0 & 0 & 0 & \\
\hline 인천의료원 & 0 & 0 & 0 & & 0 & 0 & 0 & 0 & 0 & & 0 & 0 & 0 & 0 & 0 \\
\hline 수원의료원 & 0 & & 0 & 0 & 0 & 0 & & 0 & 0 & & & 0 & 0 & & \\
\hline 의정부의료원 & 0 & 0 & 0 & & & 0 & & & 0 & 0 & & 0 & & & 0 \\
\hline 상주적십자 & 0 & & & & 0 & & & & 0 & & & & & & \\
\hline 파주의료원 & 0 & & 0 & & 0 & 0 & 0 & 0 & 0 & & & & & & \\
\hline 김천의료원 & 0 & & 0 & & 0 & 0 & 0 & & 0 & & & & & 0 & 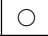 \\
\hline 천안의료원 & 0 & 0 & 0 & & 0 & 0 & 0 & 0 & 0 & & & & & 0 & 0 \\
\hline 홍성의료원 & 0 & & & & 0 & 0 & & 0 & & & & & & & \\
\hline 제주의료원 & 0 & 0 & & & 0 & 0 & 0 & 0 & 0 & 0 & 0 & 0 & 0 & 0 & 0 \\
\hline 목포의료원 & 0 & & 0 & & 0 & 0 & 0 & 0 & 0 & 0 & 0 & 0 & 0 & 0 & 0 \\
\hline 남원의료원 & 0 & & 0 & & 0 & 0 & & 0 & 0 & & 0 & 0 & & & \\
\hline 안동의료원 & 0 & 0 & 0 & & & 0 & 0 & 0 & 0 & 0 & & & & 0 & $\mathrm{O}$ \\
\hline 서귀포의료원 & 0 & & 0 & & & 0 & & & & & & & & & \\
\hline 부산의료원 & 0 & & 0 & & 0 & 0 & 0 & 0 & 0 & & 0 & 0 & 0 & 0 & \\
\hline 청주의료원 & 0 & 0 & 0 & & & 0 & 0 & 0 & 0 & & & & & 0 & \\
\hline 군산의료원 & 0 & & 0 & & 0 & 0 & & 0 & 0 & & & & & & \\
\hline 강릉의료원 & 0 & & 0 & & 0 & 0 & & & 0 & & 0 & 0 & 0 & & \\
\hline 포천의료원 & 0 & 0 & 0 & & 0 & 0 & & & 0 & & & & & 0 & \\
\hline 포항의료원 & 0 & 0 & 0 & & 0 & 0 & 0 & 0 & 0 & & & & & 0 & \\
\hline 안성병원 & 0 & 0 & 0 & 0 & 0 & 0 & 0 & 0 & 0 & & & & & & \\
\hline 대구의료원 & 0 & 0 & 0 & & & 0 & 0 & 0 & 0 & 0 & & & & 0 & \\
\hline 순천의료원 & 0 & 0 & 0 & & 0 & 0 & & & 0 & & & & & & \\
\hline 삼척의료원 & 0 & & 0 & & & & & & & & & & & 0 & $\mathrm{O}$ \\
\hline 속초의료원 & 0 & 0 & 0 & & 0 & 0 & 0 & 0 & 0 & & & & & 0 & \\
\hline 울진의료원 & 0 & & 0 & & & 0 & & 0 & & & & & & & \\
\hline 충주의료원 & 0 & & 0 & & 0 & 0 & & 0 & 0 & & 0 & 0 & & 0 & 0 \\
\hline 합계 & 27 & 12 & 24 & 3 & 19 & 25 & 14 & 19 & 23 & 6 & 7 & 10 & 7 & 15 & 9 \\
\hline 설치율(\%) & 100 & 44.4 & 88.9 & 11.1 & 70.4 & 92.6 & 51.9 & 70.4 & 85.2 & 22.2 & & 37.0 & & 55.6 & 33. \\
\hline
\end{tabular}




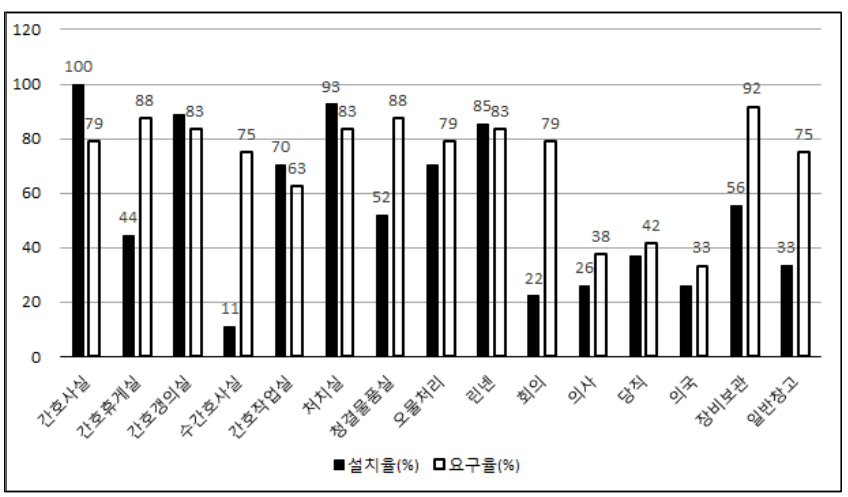

[그림 2] 간호공간 설치율과 설치요구율(\%)

2) 간호공간면적의 적정성

- 간호공간의 면적 적정성을 묻는 설문에서 간호근무실 (이후 NS로 표기)의 경우, 대체적으로 넓다는 의견을 보이고 있고, 그 외 나머지 실들은 적정과 좁음의 의견이 양분되고 있다.

- 특히, 린넨실, 오물처리실, 처치실, 간호작업실 등 실제 간 호작업공간의 면적이 좁다는 의견이 많았다.

- 간호 갱의실의 면적도 대다수 좁다는 의견이다.

- 이와 같이 간호공간의 면적 적정성에 대한 설문내용과 현 장 방문하여 도면을 수정한 병원의 실면적을 비교하여(표9), 다음에 기술하는 간호공간별 요구조건에 면적 요구를 제시하 였다.

[표 8] 간호공간 면적의 적정성(설문)

\begin{tabular}{|c|c|c|c|c|c|c|c|c|c|c|c|c|c|c|c|}
\hline 구분 & NS & $\begin{array}{l}\text { 간호 } \\
\text { 휴게 }\end{array}$ & $\begin{array}{l}\text { 간호 } \\
\text { 갱의 }\end{array}$ & $\begin{array}{l}\text { 수간 } \\
\text { 호사 }\end{array}$ & 간호억업 & \begin{tabular}{|c|} 
처치 \\
실
\end{tabular} & $\begin{array}{l}\text { 청결 } \\
\text { 물품 }\end{array}$ & 오물 & 린넨 & 회의 & 의사 & 당직 & 의국 & \begin{tabular}{|l|} 
장비 \\
보관
\end{tabular} & $\begin{array}{l}\text { 일반 } \\
\text { 창고 }\end{array}$ \\
\hline 서울의료원 & 0 & & $\nabla$ & 0 & & 0 & 0 & 0 & $\nabla$ & 0 & & 0 & 0 & $\mathrm{O}$ & \\
\hline 인천의료원 & $\Delta$ & $\nabla$ & 0 & & 0 & 0 & 0 & $\nabla$ & $\nabla$ & & 0 & 0 & 0 & 0 & 0 \\
\hline 수원의료원 & $\nabla$ & & $\nabla$ & 0 & $\nabla$ & $\nabla$ & & $\nabla$ & $\nabla$ & & & 0 & O & & \\
\hline 의정부의료원 & 0 & 0 & $\nabla$ & & & $\nabla$ & & & $\nabla$ & $\nabla$ & & $\nabla$ & & $\nabla$ & $\nabla$ \\
\hline 상주적십자 & $\nabla$ & & & $\nabla$ & & & & & & & & & & & \\
\hline 파주의료원 & $\nabla$ & & $\nabla$ & & 0 & 0 & 0 & $\nabla$ & $\nabla$ & & & & & & \\
\hline 김천의료원 & $\Delta$ & & $\nabla$ & & 0 & 0 & 0 & & 0 & & & & & 0 & 0 \\
\hline 천안의료원 & 0 & 0 & 0 & & $\nabla$ & $\nabla$ & 0 & 0 & $\nabla$ & & & & & 0 & $\nabla$ \\
\hline 홍성의료원 & $\nabla$ & & & & $\nabla$ & $\nabla$ & & $\nabla$ & & & & & & & \\
\hline 제주의료원 & 0 & 0 & & & 0 & $\nabla$ & 0 & 0 & 0 & 0 & 0 & 0 & 0 & 0 & 0 \\
\hline 목포의료원 & 0 & & & & 0 & 0 & 0 & 0 & & 0 & 0 & 0 & 0 & 0 & 0 \\
\hline 남원의료원 & $\Delta$ & $\nabla$ & $\nabla$ & & $\nabla$ & $\nabla$ & & $\nabla$ & $\nabla$ & & $\nabla$ & $\nabla$ & & & \\
\hline 안동의료원 & $\nabla$ & $\nabla$ & $\nabla$ & & & 0 & 0 & 0 & 0 & $\Delta$ & & & & 0 & 0 \\
\hline 서귀포의료원 & $\nabla$ & & $\nabla$ & & & $\nabla$ & & & & & & & & & \\
\hline 부산의료원 & $\nabla$ & & 0 & & $\nabla$ & $\nabla$ & $\nabla$ & 0 & $\nabla$ & & & & & $\nabla$ & \\
\hline 청주의료원 & $\Delta$ & $\nabla$ & $\nabla$ & & & 0 & $\nabla$ & 0 & $\nabla$ & & & & & $\nabla$ & \\
\hline 군산의료원 & $\nabla$ & & & & $\nabla$ & $\nabla$ & & $\nabla$ & $\nabla$ & & & & & & \\
\hline 강릉의료원 & 0 & & 0 & & $\nabla$ & $\nabla$ & & & $\nabla$ & & & & & & \\
\hline 포천의료원 & 0 & 0 & 0 & & 0 & 0 & & & & & & & & 0 & \\
\hline 포항의료원 & 0 & 0 & 0 & & 0 & 0 & 0 & 0 & 0 & & & & & & \\
\hline 안성의료원 & $\nabla$ & & & & & & & & & & & & & & \\
\hline 대구의료원 & $\nabla$ & $\nabla$ & 0 & & & & & & & & & & & & \\
\hline 순천의료원 & 0 & $\nabla$ & $\nabla$ & & 0 & $\nabla$ & & & $\nabla$ & & & & & & \\
\hline 삼척의료원 & $\nabla$ & & $\nabla$ & & & & & & & & & & & & $\nabla$ \\
\hline 속초의료원 & 0 & 0 & 0 & & $\nabla$ & $\nabla$ & & 0 & & & & & & $\nabla$ & \\
\hline 울진의료원 & 0 & & $\nabla$ & & & 0 & & 0 & & & & & & & \\
\hline 충주의료원 & $\Delta$ & & 0 & & 0 & 0 & 0 & 0 & 0 & & & & & 0 & 0 \\
\hline
\end{tabular}

(단위: $\mathrm{m}^{2}$ )

\begin{tabular}{|c|c|c|c|c|c|c|c|c|c|c|c|c|c|}
\hline 구분 & 군산 & 수원 & 김천 & 남원 & 안동 & 청주 & 파주 & 부산 & 안성 & 포천 & 포항 & 인천 & 비고 \\
\hline NS & 58.8 & 37.1 & 1990 & 198 & 19.7 & 55.5 & 18.9 & 14.9 & 34.7 & 32.5 & 20.2 & & NC 포함 \\
\hline 처치실 & & 18.6 & 18.5 & 9.9 & 22.5 & 20.3 & 18.9 & 19.8 & & 8.9 & \begin{tabular}{|c|}
19.4 \\
\end{tabular} & 10.3 & 공간 확보 \\
\hline 준비실 & & & 18.9 & & & & & & & 14.1 & & \begin{tabular}{|l|}
4.0 \\
\end{tabular} & \\
\hline 업실 & & & & 24.3 & & & 18.9 & & & & & 25.1 & 멱칭이 디 돟 \\
\hline 청결물실 & & & 7.3 & & & 13.3 & & & & & \begin{tabular}{|l|}
18.6 \\
\end{tabular} & \begin{tabular}{|l|}
4.2 \\
\end{tabular} & $\begin{array}{l}\text { 는 공 } \\
\text { 공간 }\end{array}$ \\
\hline 소독실 & & \begin{tabular}{|l|}
9.4 \\
\end{tabular} & & & & & & & & & \begin{tabular}{|l|}
18.6 \\
\end{tabular} & 4.3 & \\
\hline 린넨실 & & 18.3 & 8.4 & 9.9 & 7.8 & 22.1 & 3.9 & 11.5 & 16.8 & 14.9 & 17.1 & 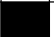 & 공간 확보 \\
\hline 오물처리실 & 2.4 & 2.6 & & 8.0 & 7.3 & & 9.5 & \begin{tabular}{|l|}
9.0 \\
\end{tabular} & & 17.4 & \begin{tabular}{|l}
5.0 \\
\end{tabular} & 8.2 & 공간 확보 \\
\hline 세탁물실 & & & & & & & 9.5 & & & & & & \\
\hline 창고 & 4.7 & & 7.4 & 4.0 & \begin{tabular}{|l|}
3.0 \\
\end{tabular} & 2.3 & & 9.05 & & 5.8 & & \begin{tabular}{|c|}
6.0 \\
\end{tabular} & 공간 확보 \\
\hline 장비보관 & 4.7 & & & & & & 18.9 & 9.1 & & 13.3 & & & 공간 확보 \\
\hline 간호사실 & 6.6 & 13.3 & 8.9 & 6.6 & & 14.4 & 7.5 & & & \begin{tabular}{|l|}
18.0 \\
\end{tabular} & & 8.4 & \\
\hline 간호휴게실 & & & 14.3 & & & & & & 14.2 & 19.1 & & & 공유 가능 \\
\hline 간호사갱의실 & 1.9 & & 9.2 & & 12.4 & & 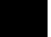 & 20.6 & & & \begin{tabular}{|l|}
9.4 \\
\end{tabular} & & \\
\hline 간호사화장실 & & 2.6 & 3.6 & & 2.7 & 3.2 & 4.5 & 4.6 & 4.32 & & 3.2 & 4.2 & 직원 공용 \\
\hline 당직실 & & 11.1 & & & 12.8 & & & & & 18.3 & & & 확보 필요 \\
\hline 스트레처/휠체어 & & & & 3.3 & & & 3.0 & & 12.0 & & & 3.6 & 공간 확보 \\
\hline 청소도구실 & & 2.9 & & 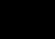 & 5.6 & & & & & & & & 공간 확보 \\
\hline 배선실 & & 18.3 & 19.4 & 7.9 & 17.6 & 15.5 & 9.5 & 18.2 & 15.4 & 17.4 & & 11.8 & \\
\hline 용역원실 & & & 12.6 & & \begin{tabular}{|l|}
10.8 \\
\end{tabular} & & & & & & 18.7 & & 간병인 포함 \\
\hline 취사실 & 16.8 & & & & 18.7 & & & $\mid 17.9$ & 16.1 & & 29.5 & & 간이주방 \\
\hline 의국 & & & & & & & & 40.0 & & 34.8 & & 20.0 & 교육연구 \\
\hline 회의실 & & & & \begin{tabular}{|c|}
14.4 \\
\end{tabular} & $38 \div$ & & & & 55.5 & 14.1 & & & 팀 회의 \\
\hline
\end{tabular}

주) 녑 넉섬

3) 간호공간별 조건

(1) NS

- 의료진 및 간호사에 의한 처치, 차팅, 물품수납, 환자치료 계획 수립 등 병동업무의 거점이다.

- 간호업무의 효율성을 위해 NS, 작업실, 처치실, 린넨고, 청결물품실, 오물처리실은 인접 배치하는 것이 좋다.

- NS는 병동 출입을 쉽게 통제할 수 있고, 휴게실, 식당 등 을 쉽게 관찰할 수 있고 접근이 용이하도록 배치한다.

- 기록 작업을 위한 공간과 컴퓨터 및 환자감시용 모니터를 배치할 수 있는 공간을 확보하고 붙박이 서류장, 세면대 등을 설치한다.

- 너무 콤팩트한 원룸형의 간호제실은 공간부족과 혼란을 초래할 수 있다. 반면, 너무 넓은 NS는 전체 간호제실의 면적 안배에 불균형을 초래하게 된다.

- 공공병원은 팀 간호 방식을 도입해도 인력 문제로 널스 코너(Nurse Corner)에 의한 분산 운영이 어렵다. 따라서 기존 의 NS를 병실 중앙부에 설치하여 팀 간호의 거점으로 사용하 는 방법을 고려하고, 추후 인력 대비 효과적인 평면에 대한 연 구가 필요하다.

$\mathrm{NS}$ 의 면적 현황은 다소 상반된 결과를 보이고 있는데, 50 $\mathrm{m}^{2}$ 이상의 면적은 넓고, $20 \mathrm{~m}^{2}$ 정도의 면적은 적정과 좁음, 넓음 의 의견이 중복되어 있어, 그 이상 필요할 것으로 보인다. 포 천병원은 $30 \mathrm{~m}^{2}$ 정도의 면적이 적정하다는 의견이다.

(2) 간호작업실/ 청결물품실 
- 처치실 등에서 사용되는 소독물 및 의료장비를 접수, 보 관하여 처치와 간호를 준비하는 곳으로 청결물실, 소독물실과 같은 공간이다. 투약준비, 주사준비 및 처치준비 행위가 일어 나므로 처치실, NS와 인접해야 한다. 간호용구와 기자재 등의 수납선반, 기구류를 펼쳐놓는 탁자, 투약고, 카트공간 등이 필 요하다.

- 공공병원에서는 NS 원룸형, 작업실형, 작업실+청결물품 (소독품) 분리형 등 몇가지 유형이 나타나고 있다.

- 면적은 청결물품실을 포함하여 최소 $20 \mathrm{~m}^{2}(1 / 2$ 모듈) 정도 필요하다.

- 준비실, 작업실, 청결물실, 소독실은 각각 실명은 다르지 만, 같은 기능 또는 오픈 공간으로 사용되거나 인천의료원과 같이 모든 실이 분할된 병원의 예도 있다. 전체적으로 $20 \mathrm{~m}^{2}$ (1/2모듈) 전후에서 30 40 $\mathrm{m}^{2}$ 정도의 면적이 필요하다.

(3) 린넨실

- 병동에 필요한 각종 린넨을 보관하는 공간이다.

- NS에 인접하는 것이 좋다. 분산형으로 할 경우, 병실에 인접 배치할 수 있다.

- 용도에 맞는 붙박이 장을 벽면에 설치하고, 린넨 작업이 필요한 경우를 대비하여 간단한 작업대를 설치한다.

- 물품공급부서의 공급정책에 따라 보관실의 크기가 변동 될 수 있는데, 공공병원은 $20 \mathrm{~m}^{2}(1 / 2$ 모듈) 이상의 큰 공간을 갖 는 병원도 있다. 그러나 이것은 다른 용도(주로 처치실)의 실 과 복합된 것으로 순수 린넨실 만의 면적은 최대 $10 \mathrm{~m}^{2}(1 / 4$ 모 듈)면 충분하다.

(4) 처치실

- 처치실에서는 검사와 진단, 응급처치, 일상 처치와 드레 싱 등의 행위가 일어나며, 환자가 휠체어, 스트레처, 병상 등 을 이용해 방문하여 처치를 받는다.

- 처치실에는 청결작업대, 처치대, 보관대, 싱크, 준비대 등 이 요구되며, NS와 직접 연결시키거나 근접하여 배치한다. 싱 크는 발로 작동할 수도 있도록 한다.

- 스트레처로 환자를 쉽게 이동할 수 있도록 문의 폭을 충 분히 확보한다.

- 처치실의 바닥과 벽은 세척이나 소독을 쉽게 할 수 있는 재료를 사용한다.

- 간호작업실 또는 청결물 창고와 인접하도록 하고, 수세시 설과 간이 침상을 설치하고, 응급상황에 따라 의료가스 설비 를 확보한다.

- 병동 중앙부에 위치하는 것이 환자에게 유리하다.

- 면적은 $10 \mathrm{~m}^{2}\left(1 / 4\right.$ 모듈) 정도의 병원도 있으나 보통 $15 ~ 20 \mathrm{~m}^{2}$ (1/2모듈) 정도 필요하다.

(5) 간호사실/ 갱의실/ 휴게실/ 화장실

- 간호사의 갱의, 세면 및 휴식을 위한 공간으로 옷장, 탁자, 의자, 세면대 등을 설치한다.
- 각각의 분리된 실을 설치한 병원도 있으나 각 공간을 공 유하는 것이 가능하다.

- 환자와 접촉하지 않는 장소로 안락의자와 탕비 코너를 두 면 좋다.

- 간호사실, 간호휴게실, 간호갱의실은 공유가 가능하고 합 계 $20 \mathrm{~m}^{2}(1 / 2$ 모듈 $)$ 정도 필요하다.

- 간호사 화장실은 직원화장실로 활용할 수 있도록 간호사 실에 인접 배치하되, 밖에서 출입할 수 있도록 고려한다. $3 \sim 5 \mathrm{~m}^{2}$ 정도이다.

(6) 오물처리실

- 오염된 린넨을 모으고 처치에 사용된 기기를 세척하는 곳 으로 수액처리와 빈 용기 저장 및 세척을 한다.

- 사용된 린넨, 쓰레기, 검체 등의 일시 보관을 위한 시설 을 갖추고 오물처리 등을 위한 변기세척기 및 싱크 등을 설 치한다.

- 오염된 물품(적출물, 수액병, 오염린넨 등)을 분리수거할 수 있는 공간을 고려한다.

- 환기가 잘되도록 계획하고, 오염된 기구를 세척할 수 있 는 싱크와 발로 작동할 수 있는 오물처리기를 설치한다.

- 처치실이나 청결물실에 인접 배치한다.

- 세탁물실을 별도로 설치하는 병원도 있으나 이를 포함하여 $10 \mathrm{~m}^{2}(1 / 4$ 모듈 $)$ 정도의 면적이 필요하다.

(7) 배선실

- 환자를 위한 배식공간으로 작업대, 냉장고, 온장고, 전자 렌지, 싱크, 수납장, 음수대 등을 설치하고, 식당과 배식공간과 의 동선을 고려한다.

- 배선실은 배선차 적치장으로서 불규칙적인 식사가 필요 한 환자를 위해 보온 및 저온설비가 필요하다.

- 현재, 배선실에는 간이주방을 설치하고 간단한 테이블을 두어 간병인 식사실을 겸하고 있는 병원이 많다.

- 환자식당을 설치하는 경우, 배선실과의 동선을 고려해야 한다.

- 면적은 $20 \mathrm{~m}^{2}(1 / 2$ 모듈) 정도 필요하고, 2 개 병동에서 공유 한다.

(8) 스트레처/ 휠체어 보관실

- 병동의 출입구 또는 NS에 인접해야 한다.

- 별도의 공간보다는 상부는 수납장, 하부는 휠체어 보관 등으로 사용하면 효율적이다.

- 휠체어 보관고의 용도로 할 경우, $3 \sim 4 \mathrm{~m}^{2}$ 필요하다.

(9) 기기 보관고/ 일반창고/ 청소도구실

- 병동 내 물품은 그 종류와 요구되는 청결도에 따라 각기 보관될 수 있도록 린넨실(환의 및 침대보 등), 청결물 보관실 (주사약, 위생재료 등), 오물처리실(사용된 물품의 일시보관, 오물처리), 일반창고(각종 미사용품, 수액류), 휠체어 및 스트 레처 보관 공간 등으로 구분하여 설치한다. 
- 기기보관고/ 창고와 청소도구실은 일반적으로 누락되는 경 우가 많은데, 반드시 필요한 공간이다. 특히 기기 보관고는 공 공병원 사례에서 보듯이 그 양도 많고 면적도 상당히 필요하다.

- 창고와 장비 보관고는 공간 확보가 필요한데, 창고는 $5 \sim 10\left(1 / 8\right.$ 모듈 $1 / 4$ 모듈), 장비 보관고는 $10 \mathrm{~m}^{2}(1 / 4$ 모듈)보다 큰 공 간이 요구된다.

청소 도구실은 공간 확보가 필요하고, 3 6 $\mathrm{m}^{2}$ 정도이다.

\section{4-2 Convenient Facilities of the Patient}

1) 환자편의공간의 설치율과 설치 요구율

(1) 환자편의공간의 설치율

- 공용공간의 설치율(간호사, 환자 설문)은 식당, 면회실, 세 탁실, 휠체어보관, 간병인 갱의실이 낮고, 취사실과 청소도구 실도 낮은 편이다.

- 환자휴게실, 공용화장실, 장애인화장실, 공용욕실, 배선실 은 설치율이 매우 높다.

- 현재 면회와 식당, 휴게 공간 등은 혼용되고 있다.

- 장비보관과 일반창고는 주요공간에 밀려 고려대상에서 누락되는 경우가 많은데, 반드시 확보해야 한다.

(2) 환자편의공간의 설치 요구율

(1) 간호사 의견

- 절대적인 요구율이 높은 공용공간은 휠체어보관, 청소도 구실이다.

- 현재 설치율과 비교해 요구도가 높은 공간은 식당, 취사 실, 면회실, 세탁실, 간병인 갱의실이 있다.

(2) 환자의 의견

- 환자의 요구율은 장애인화장실, 공공화장실, 환자휴게실, 공동욕실, 배선실, 휠체어보관실의 순으로 나타났으며, 이외 의 시설 설치 요구율은 다소 떨어진다.

- 이것은 대부분 환자가 직접 사용하는 공간에 높은 수준의 설치요구를 한 것으로 보이며, 간호사의 입장과는 다소 차이 가 있다.

- 식사실은 $58 \%$ 로 가장 낮은 순위이다.

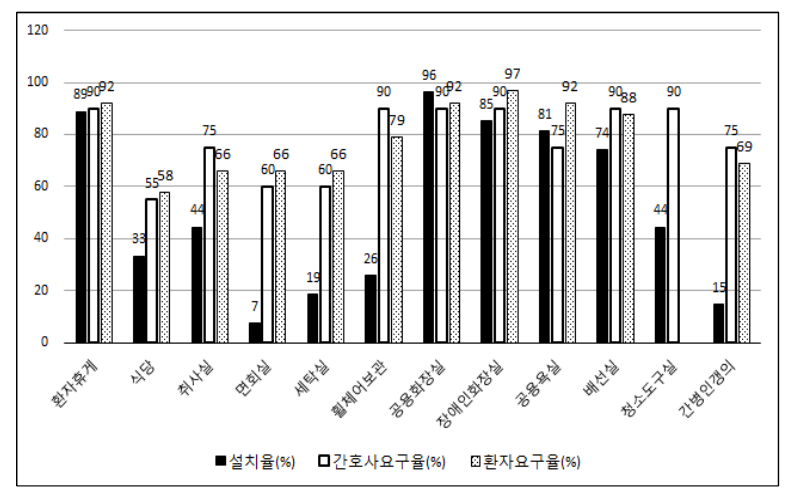

[그림 3] 공용공간 설치율과 요구율(\%)

2) 환자 편의공간 면적의 적정성
- 공용공간에서 환자휴게실이 넓다는 의견이 많았다.

- 면적이 없거나 협소한 공간은 공용화장실, 장애자화장실, 욕실, 배선실, 청소도구실 등으로 검토가 필요하다.

[표 10] 환자 편의공간 면적의 적정성 분석

(단위: $\mathrm{m}^{2}$ )

\begin{tabular}{l|c|c|c|c|c|c|c|c|c|c|c|c|c|c}
\hline \multicolumn{1}{c|}{ 구분 } & 군산 & 수원 & 김천 & 남원 & 안동 & 청주 & 파주 & 부산 안성 & 포천 & 포항 & 인천 & 비고 \\
\hline 데이룸 & 238.8 & 10.2 & 84 & 39.6 & 52.3 & 31.5 & 50.0 & 38.1 & & & 13.4 & 3.3 & \\
\hline 공용화장실 & 5.5 & 18.3 & 45.8 & 8.3 & 24.9 & 18.4 & 18.9 & 16.0 & 32.5 & 38.5 & 10.2 & 4.6 & 장애인 포함 \\
\hline 공용화장실 & 7.1 & 18.3 & 28.6 & 8.3 & 35.9 & 18.4 & 18.9 & 20.3 & 33.9 & 33.9 & 37.7 & 4.6 & 장애인 포함 \\
\hline 장애인화장실 & 4.7 & & & 5.2 & & 3.6 & & & & & & & \\
\hline 공용욕실 & 7.1 & & 36.0 & 10.4 & 17.1 & 18.4 & 8 & & & & 37.7 & & 좌욕실 포함 \\
\hline 좌욕실 & 22.4 & 2.2 .0 & & & 8.9 & 7.6 & 18.9 & & & & & & \\
\hline 환자식당 & & & & & & & & 18.5 & & & 35.8 & & 간이주방포함 \\
\hline
\end{tabular}

주)

3) 환자편의 공간별 조건

(1) 휴게실

- 휴게실(데이룸)은 병동당 1 개 이상을 설치하여 휴게, 담 화, TV시청, 독서, 면회 등으로 이용하는 기분전환의 공간으로 서, 주 사용목적은 담화와 휴식, TV시청이라고 볼 수 있다.

- 휴게실에서 시간을 정해놓고 식사실과 겸용하는 병원이 있으나 음식냄새와 세균, 미세먼지 등으로 공용으로 하기에는 불편하다.

- TV는 병실에서 소음문제로 없애고, 휴게실에 설치하여 시청하도록 하는 요구가 있다.

- 휴게실의 불편사항으로는 소음, 공간협소, TV없음, 의자 및 탁자 없음, 인터넷 문제 등이 지적되었다. 특히, 대부분의 공공병원은 큰 휴게공간을 설치해 놓고 있으나 형식상의 공 간뿐으로 필요한 가구나 설비, 운영프로그램이 별로 없는 실 정이다. 군산의료원은 인터넷, 게임, 운동기구, 자판기 등 다른 병원에 비해 다양한 코너가 마련되어 있다.

- 휴게실의 성격상 여러 행위가 복합되므로 가장 큰 불편사 항이 소음이다. 따라서 휴게실을 조용한 휴게실과 시끄러운 휴게실로 구분하는 것이 바람직하다.

- 휴게실의 면적은 $10 \mathrm{~m}^{2}(1 / 4$ 모듈 $)$ 에서 $80 \mathrm{~m}^{2}$ 까지 나타나고 있는데, 보통 $40 \mathrm{~m}^{2}(1$ 모듈)를 사용하고 있다.

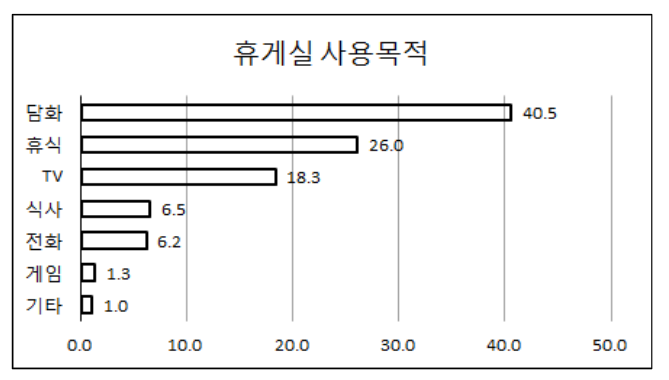

[그림 4] 휴게실의 사용목적 


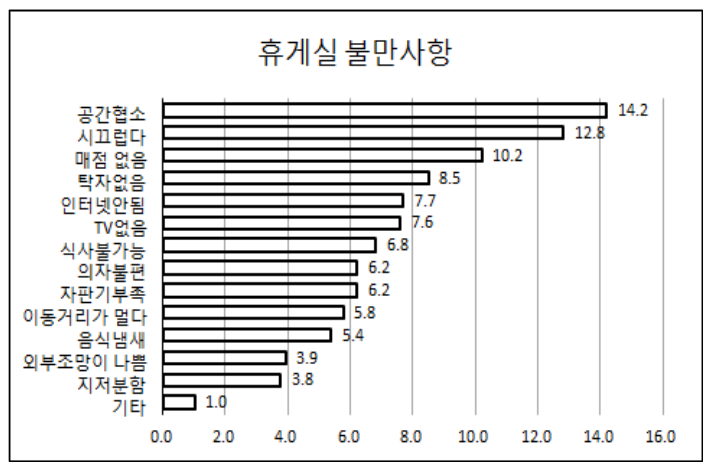

[그림 5] 휴게실의 불편사항

(2) 식사공간

(1) 간호사 의견

- 현재 식사는 거의 병실에서 이루어지고 있다.

- 향후에도 환자는 병실에서 식사해야 한다는 의견이 지배 적이다.

- 보호자, 간병인은 식사실이 필요하다는 의견이 많다.

- 식사실의 필요기기는 간이주방, 음수대, 음료자판기이며, 필요한 기기만 간단히 있고, 이외의 다른 가구는 배치하지 않 는 것이 좋다는 의견이다.

(2) 입원환자 의견

- 현재 식사는 환자, 보호자, 간병인 모두 주로 병실에서 하 고 있다.

- 간병인의 경우는 일부 병원에서 배선실에 테이블을 비치 해 식사실로 사용하고 있다.

[표 11] 환자의 식사공간

\begin{tabular}{|c|c|c|c|c|c|c|c|c|c|c|c|}
\hline \multirow[b]{2}{*}{ 구분 } & \multicolumn{3}{|c|}{ 현재 식사공간 } & \multicolumn{3}{|c|}{ 향후 희망 식사공간 } & \multicolumn{5}{|c|}{ 기기구비 } \\
\hline & 환자 & 보호지 & |간병인 & 환자 & 보호자 & 간병인 & $\begin{array}{l}\text { 간일 } \\
\text { 방 }\end{array}$ & 주음수대 & \begin{tabular}{|c|} 
음료 \\
자판기
\end{tabular} & TV & $\begin{array}{l}\text { 무선 } \\
\text { 인터넷 }\end{array}$ \\
\hline 서울의료원 & 병실 & 병실 & 병실 & 병실 & 병실 & 병실 & & 0 & 0 & 0 & \\
\hline 인천의료원 & 병실 & 병실 & 병실 & 식사실 & 식사실 & 식사실 & 0 & 0 & 0 & & \\
\hline 수원의료원 & 병실 & 병실 & 병실 & 병실 & 휴게실 & 휴게실 & $\mathrm{O}$ & $\mathrm{O}$ & & & \\
\hline 의정부의료원 & 병실 & 병실 & 병실 & 병실 & 식사실 & 식사실 & $\mathrm{O}$ & 0 & & & \\
\hline 상주적십자 & 병실 & 병실 & 병실 & 병실 & 식사실 & 식사실 & $\mathrm{O}$ & $\mathrm{O}$ & $\mathrm{O}$ & 0 & \\
\hline 파주의료원 & 병실 & 병실 & 병실 & 병실 & 병실 & 병실 & $\mathrm{O}$ & $\mathrm{O}$ & & & \\
\hline 김천의료원 & 병실 & 병실 & 외부 & 병실 & 병실 & 식사실 & 0 & 0 & & & \\
\hline 천안의료원 & 병실 & 병실 & 병실 & 병실 & 병실 & 병실 & 0 & 0 & & & \\
\hline 홍성의료원 & 병실 & 병실 & 휴게실 & 식사실 & 식사실 & 식사실 & $\mathrm{O}$ & $\mathrm{O}$ & & & \\
\hline 제주의료원 & 병실 & 휴게실 & 배선실 & 병실 & 휴게실 & 식사실 & 0 & 0 & 0 & & \\
\hline 목포의료원 & 병실 & 병실 & 병실 & 병실 & 병실 & 병실 & 0 & 0 & & & \\
\hline 남원의료원 & 병실 & 병실 & 병실 & 병실 & 식사실 & 식사실 & 0 & 0 & 0 & 0 & \\
\hline 안동의료원 & 병실 & 병실 & 배선실 & 병실 & 식사실 & 식사실 & 0 & 0 & 0 & 0 & 0 \\
\hline 서귀포의료원 & 병실 & 병실 & 병실 & 병실 & 식사실 & 식사실 & 0 & 0 & 0 & & \\
\hline 부산의료원 & 병실 & 병실 & 병실 & 병실 & 식사실 & 식사실 & 0 & & & & \\
\hline 청주의료원 & 병실 & 병실 & 병실 & 식사실 & 식사실 & 식사실 & 0 & 0 & & & \\
\hline 군산의료원 & 병실 & 병실 & 병실 & 병실 & 식사실 & 식사실 & & 0 & 0 & & \\
\hline 강릉의료원 & 병실 & 병실 & 병실 & 병실 & 식사실 & 병실 & 0 & 0 & 0 & & \\
\hline 포항의료원 & 병실 & 병실 & 휴게실 & 병실 & 병실 & & 0 & 0 & & & \\
\hline 안성의료원 & 병실 & 병실 & 병실 & 병실 & 식사실 & 식사실 & 0 & 0 & & 0 & \\
\hline 대구의료원 & 병실 & 병실 & 병실 & 병실 & 식사실 & 병실 & & 0 & & 0 & \\
\hline 순천의료원 & 병실 & 병실 & 병실 & 병실 & 식사실 & 병실 & $\mathrm{O}$ & $\mathrm{O}$ & & & \\
\hline 삼척의료원 & 병실 & 병실 & 병실 & 병실 & 식사실 & 식사실 & 0 & 0 & & 0 & 0 \\
\hline 속초의료원 & 병실 & 병실 & 병실 & 병실 & 식사실 & 식사실 & 0 & 0 & 0 & & \\
\hline 울진의료원 & 병실 & 식사실 & 식사실 & - & - & - & 0 & 0 & 0 & 0 & \\
\hline 충주의료원 & 병실 & 병실 & 병실 & - & 식사실 & 식사실 & 0 & 0 & & 0 & \\
\hline
\end{tabular}

[표 12] 식사공간 현황 및 의견(\%)

\begin{tabular}{c|c|c|c|c|c}
\hline \multicolumn{2}{|c|}{ 구분 } & 병실 & 휴게실 & 식사실 & 기타 \\
\hline \multirow{2}{*}{$\begin{array}{c}\text { 현재 상태 } \\
\text { (\%) }\end{array}$} & 환자 & 98.5 & 0.4 & 1.2 & \\
\cline { 2 - 6 } & 보호자 & 82.9 & 7.5 & 7.3 & 2.3 \\
\cline { 2 - 6 } & 간병인 & 77.9 & 6.4 & 15.1 & 0.6 \\
\hline \multirow{2}{*}{$\begin{array}{c}\text { 향후 의견 } \\
\text { (\%) }\end{array}$} & 환자 & 83.7 & 2.9 & 13.4 & \\
\cline { 2 - 6 } & 보호자 & 46.6 & 12.0 & 41.4 & \\
\cline { 2 - 6 } & 간병인 & 37.8 & 10.4 & 51.7 & \\
\hline
\end{tabular}

[표 13] 기기구비 (478명 설문)

\begin{tabular}{c|c|c|c|c|c}
\hline 구분 & 간이주방 & 음수대 & 음료자판기 & TV & 무선인터넷 \\
\hline 응답수 & 298 & 235 & 97 & 129 & 83 \\
\hline 비율 & 62.3 & 49.2 & 20.3 & 27.0 & 17.4 \\
\hline
\end{tabular}

- 향후에도 환자의 경우는 병실이 식사하기 편하다는 의견 이 지배적이다. 단, 활동이 가능한 환자의 경우는 식사실로 걸 어가는 것이 치료에 도움이 된다는 의견이 있다.

- 환자보다는 보호자와 간병인을 위한 식사실이 필요하다 는 의견이 많았다.

- 식사실의 기기로는 간이주방, 음수대, TV, 음료자판기, 무 선인터넷 순으로 필요하다는 의견이며, 간이주방에는 전자레 인지를 포함해야한다는 의견이다.

(3) 식사실의 요구조건

- 환자보다는 보호자와 간병인에게 필요한 시설로 조사되 었으나 식사실을 설치하여 환자, 보호자, 간병인을 위한 만남 의 공간으로 운영하는 것이 바람직하다.

- 식사실은 병동, 층, 또는 병원 전체를 대상으로 할 수 있 으나 층별로 식사실을 운영하는 것이 일손의 절약에 도움이 된다.

- 그러나 매식마다 병실과 식사실에서 식사하는 환자를 파 악해야 하는 간호업무가 늘어난다.

- 한 층당 1 개의 식사실을 설치할 경우, 층의 중심부에 배 선실과 가깝고 외부조망이 가능한 장소에 설치하고, 면적은 2 개 병동이 공동으로 $40 \mathrm{~m}^{2}$ (1모듈) 정도 사용한다.

(3) 화장실

- 병실에 화장실이 설치되므로 공용화장실의 필요성이 과 거보다 낮아졌으나, 방문자와 데이룸 이용자 등 병실 외부에 공용화장실의 필요성이 있다.

- 화장실은 공간이 충분할 경우, 일반 화장실과 함께 장애 자용 화장실(최소 $\left.3.6 \mathrm{~m}^{2}\right)$ 을 대칭구조로 2 개소 설치한다. 공간 이 부족할 경우, 일반화장실 내에 장애인화장실을 설치하거나 남녀 구분 없이 장애인 화장실 1 개소를 설치하고, 경사거울, 세면대, 좌변기 및 널스콜 등을 설치한다.

- 화장실에는 수동식 비데를 설치하고, 세척과 청소비품, 
환자보조용품 보관공간을 설치한다.

- 면적은 장애인화장실을 포함할 경우, 남녀를 구분하고 각 각 $20 \mathrm{~m}^{2}(1 / 2$ 모듈 $)$ 정도이다.

(4) 욕실/ 좌욕실/ 세면실/ 샤워실

- 욕실은 병동의 중앙에 배치하여 환자의 이동 동선을 짧게 하고, 간호 팀 간의 공동 사용이 편리하게 한다.

- 욕실 벽면에는 목욕용품 및 린넨 등을 보관할 수 있는 수 납장을 설치한다.

- 바닥은 미끄럼방지 재료를 사용하며, 다소 경사지게 하여 물이 욕실 밖으로 흘러나오지 않도록 한다.

- 병원에 따라 욕실보다 세면 및 샤워실의 요구가 높을 경 우, 대체 가능하다.

- 욕실문에는 문턱을 두지 않는다.

\section{4-3 Satisfactions of the Wards}

- 간호사 27 개 병원, 환자 539 명의 설문을 분석하였다.

- 병동부의 전체적인 만족도는 대체적으로 높다(간호사 3.48/5점, 환자 3.65점/5점).

- 간호사보다 환자의 만족도가 높다.

- 공용화장실, 장애인화장실에 대한 만족도가 가장 높다 $(3.67,3.70)$.

- 간병인 탈의공간에 대한 만족도가 가장 낮다.(3.12). 별도 의 공간이 필요하다.

- 식사실/ 세탁실 등의 만족도가 다소 낮다(3.37, 3.36). 이 들을 설치한 병원이 적어 다른 용도의 공간과 혼합되어 사용 됨으로서 생기는 불만으로 사료된다.

- 인터넷실에 대한 만족도가 다소 낮다(3.15). 유무선 인터 넷이 제한적인 병원이 다소 있다. 부산의료원의 경우 보안상 이유로 무선인터넷을 제한하고 있다.

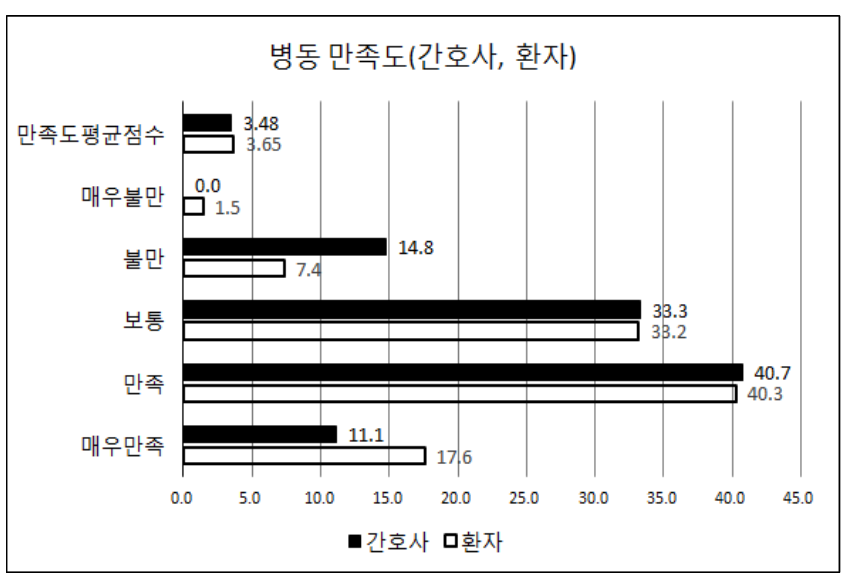

[그림 6] 병동 만족도(간호사, 환자)
[표 14] 시설별 만족도

\begin{tabular}{c|c|c|c|c|c|c|c}
\hline 구분 & 응답수 & $\begin{array}{c}\text { 매운 } \\
\text { 만촉 }\end{array}$ & 만족 & 보통 & 불만 & $\begin{array}{c}\text { 매웅 } \\
\text { 불만 }\end{array}$ & $\begin{array}{c}\text { 평균 } \\
\text { 만족도 }\end{array}$ \\
\hline 환자휴게실 & 393 & 13.2 & 38.7 & 34.4 & 9.9 & 3.8 & 3.48 \\
\hline 면회실 & 170 & 14.7 & 37.6 & 32.9 & 10.6 & 4.1 & 3.48 \\
\hline 식사실 & 169 & 13.6 & 32.5 & 36.7 & 11.2 & 5.9 & 3.37 \\
\hline 세탁실 & 180 & 15.6 & 28.9 & 36.7 & 13.3 & 5.6 & 3.36 \\
\hline 취사실 & 221 & 15.4 & 36.7 & 30.8 & 12.2 & 5.0 & 3.45 \\
\hline 휠체어보관 & 208 & 16.8 & 35.1 & 34.1 & 8.7 & 5.3 & 3.50 \\
\hline 공용화장실 & 387 & 22.0 & 39.5 & 24.8 & 10.9 & 2.8 & 3.67 \\
\hline 장애인화장실 & 343 & 21.0 & 43.1 & 24.8 & 7.0 & 4.1 & 3.70 \\
\hline 공동욕실 & 356 & 17.1 & 35.1 & 33.1 & 10.7 & 3.9 & 3.51 \\
\hline 배선실 & 315 & 16.8 & 36.8 & 36.2 & 8.3 & 1.9 & 3.58 \\
\hline 인터넷실 & 151 & 10.6 & 27.8 & 35.1 & 19.2 & 7.3 & 3.15 \\
\hline 간병인탈의실 & 110 & 12.7 & 20.9 & 40.9 & 16.4 & 9.1 & 3.12 \\
\hline
\end{tabular}

\section{Conclusion}

본 연구를 통해 다음과 같은 지역거점 공공병원 병동부의 건축계획 기준을 제시하였다.

1) 공공병원의 평면유형은 중복도형과 이중복도형을 중 심으로 구성하고, 팀간호에 대응한 평면유형의 도입을 검토 한다.

2) 간호운영방식은 팀 간호방식을 기반으로 한다.

3) 간호단위당 병상수는 팀 간호 운영에 따라 45 60병상 (팀당 15명 20명 X 3팀)으로 운영한다.

4) 공공병원 1 개 병동의 면적구성은 중복도형 $20 \mathrm{~m}^{2} / \mathrm{Bed}$, $\mathrm{G} / \mathrm{N}$ 비 1.5 , 이중복도형 $26 \mathrm{~m}^{2} / \mathrm{Bed}, \mathrm{G} / \mathrm{N}$ 비 1.6 정도로 한다.

5) 간호공간의 실구성은 NS, 간호작업실(준비실, 청결물품 실, 소독실), 린넨실, 오물처리실(세탁물수집 포함), 간호사실 (갱의, 휴게 포함), 직원화장실, 배선실, 용원실(간병인실 포 함), 회의실, 기기보관고, 일반물품창고, 스트레처/휠체어 보 관, 청소도구실, 당직실, 의국 등으로 구성한다.

6) 환자편의시설은 휴게실(정적, 동적 공간 구분), 식사실, 공용화장실(장애인 포함), 욕실(세면실, 샤워실 포함)로 구성 한다.

7) NS는 팀 간호 도입에 적합하도록 분산된 널스 코너가 필요하다. 그러나 인력이 부족한 공공병원의 경우, 분산운영 이 어려우므로 하나의 NS로 통합하여 운영할 수 있으며, 이 경우, 병실군의 중앙부에 배치하여 각 팀의 동선 효율성을 높 이도록 한다.

8) 연구의 종합으로 스페이스 프로그램과 평면 예시안을 제시한다(표 15, 그림 7, 그림 8).

9) 평면 예시안은 동일조건 하에서 중복도형과 이중복도형 으로 작성하였다. 중복도형 평면 예시안은 길이 $126.9 \mathrm{~m}$, 폭 $22.5 \mathrm{~m}$, 총면적 $2,189 \mathrm{~m}^{2}$, 병상당 면적 $21.9 \mathrm{~m}^{2}$ 이며, 이중복도형 
평면 예시안은 길이 $95.1 \mathrm{~m}$, 폭 $25.8 \mathrm{~m}$, 총면적 $2,466 \mathrm{~m}^{2}$, 병상 당 면적 $24.6 \mathrm{~m}^{2}$ 이다.

10) 예시안은 경영방식과 지역, 주어진 현안 등에 따라 조 정되고 응용되어야 한다.

[표 15] 공공병원 병동부 스페이스 프로그램 예시안

\begin{tabular}{c|l|c|c|c|l}
\hline 구분 & \multicolumn{1}{|c|}{ 실명 } & $\begin{array}{c}\text { 단위면적 } \\
\left(\mathrm{m}^{2}\right)\end{array}$ & 실수 & $\begin{array}{c}\text { 계 } \\
\left(\mathrm{m}^{2}\right)\end{array}$ & \multicolumn{1}{|c}{ 비고 } \\
\hline 1 & 1 인실 & 20 & 2 & 40 & 화장실, 샤워실 포함 \\
\hline 2 & 2 인실 & 23 & 2 & 46 & 화장실, 샤워실 포함 \\
\hline 3 & 4 인실 & 36 & 11 & 396 & 화장실, 샤워실 포함 \\
\hline 4 & 데이룸 & 40 & 1 & 40 & 분산 또는 통합 배치 가능 \\
\hline 5 & 환자식당 & 40 & 0.5 & 20 & \\
\hline 6 & 공용화장실 & 20 & 1 & 20 & 남녀구분 \\
\hline 7 & 장애인화장실 & 5 & 1 & 5 & \\
\hline 8 & 공용목욕실 & 15 & 1 & 15 & 남녀구분 \\
\hline 9 & NS & 30 & 1 & 30 & 반송설비, 회의실 포함 \\
\hline 10 & 처치실 & 15 & 1 & 15 & 의료가스, 싱크대설치(상부장 포함) \\
\hline
\end{tabular}

\begin{tabular}{|c|c|c|c|c|c|}
\hline 구분 & 실명 & $\begin{array}{c}\text { 단위면적 } \\
\left(\mathrm{m}^{2}\right)\end{array}$ & 실수 & \begin{tabular}{|c|} 
계 \\
$\left(\mathrm{m}^{2}\right)$
\end{tabular} & 비고 \\
\hline 11 & 작업실 & 15 & 1 & 15 & \\
\hline 12 & 청결물실 & 15 & 1 & 15 & \\
\hline 13 & 린넨실 & 10 & 1 & 10 & 선반설치 \\
\hline 14 & 오물처리실 & 10 & 1 & 10 & clinical 싱크 설치 \\
\hline 15 & 간호사실 & 20 & 1 & 20 & 화장실 및 옷장 포함 \\
\hline 16 & 창고 & 10 & 2 & 20 & 기기창고, 휠체어보관, 일반창고 \\
\hline 17 & 당직실 & 20 & 0.5 & 10 & 화장실 및 샤워실 포함 \\
\hline 18 & 의국 & 20 & 0.5 & 10 & \\
\hline 19 & 회의실 & 15 & 1 & 15 & 면회실 겸용 \\
\hline 20 & 청소도구실 & 2 & 1 & 2 & 갱의공간 포함, 청소용싱크설치 \\
\hline 21 & 배선실 & 20 & 0.5 & 10 & 주방 싱크대/ 정수기 설치 \\
\hline 22 & 간병인탈의실 & 4 & 2 & 8 & \\
\hline & 순면적 & & & 772 & 50 병상 \\
\hline $\mathrm{G} / \mathrm{N}$ & 중복도형 & & & 1.45 & 총면적비 \\
\hline 비 & 이중복도형 & & & 1.60 & 총면적비 \\
\hline 총 & 중복도형 & & & 1,120 & $22.4 \mathrm{~m}^{2} / \mathrm{bed}$ \\
\hline 면적 & 이중복도형 & & & 1,235 & $24.7 \mathrm{~m}^{2} / \mathrm{bed}$ \\
\hline
\end{tabular}

주) - 병실구성은 1인 2실, 2인 2실, 4인 11실로 가정 - 1 개층 2 개 간호단위(50병상) 가정

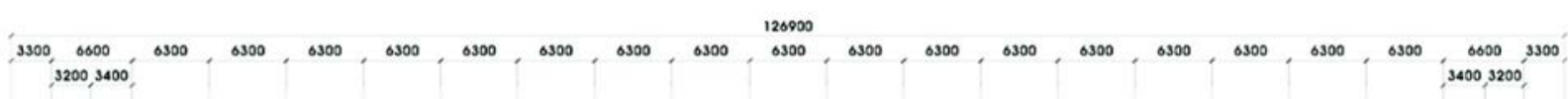

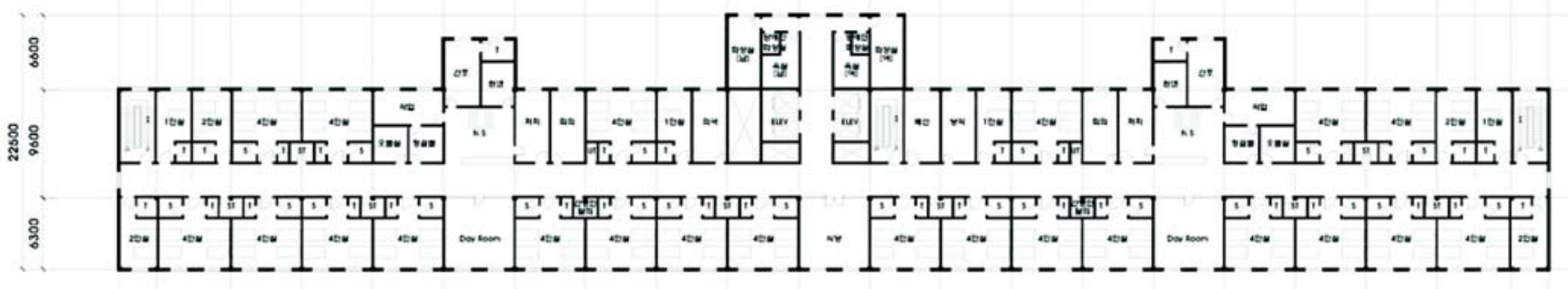

[그림 7] 중복도형 병동 예시안
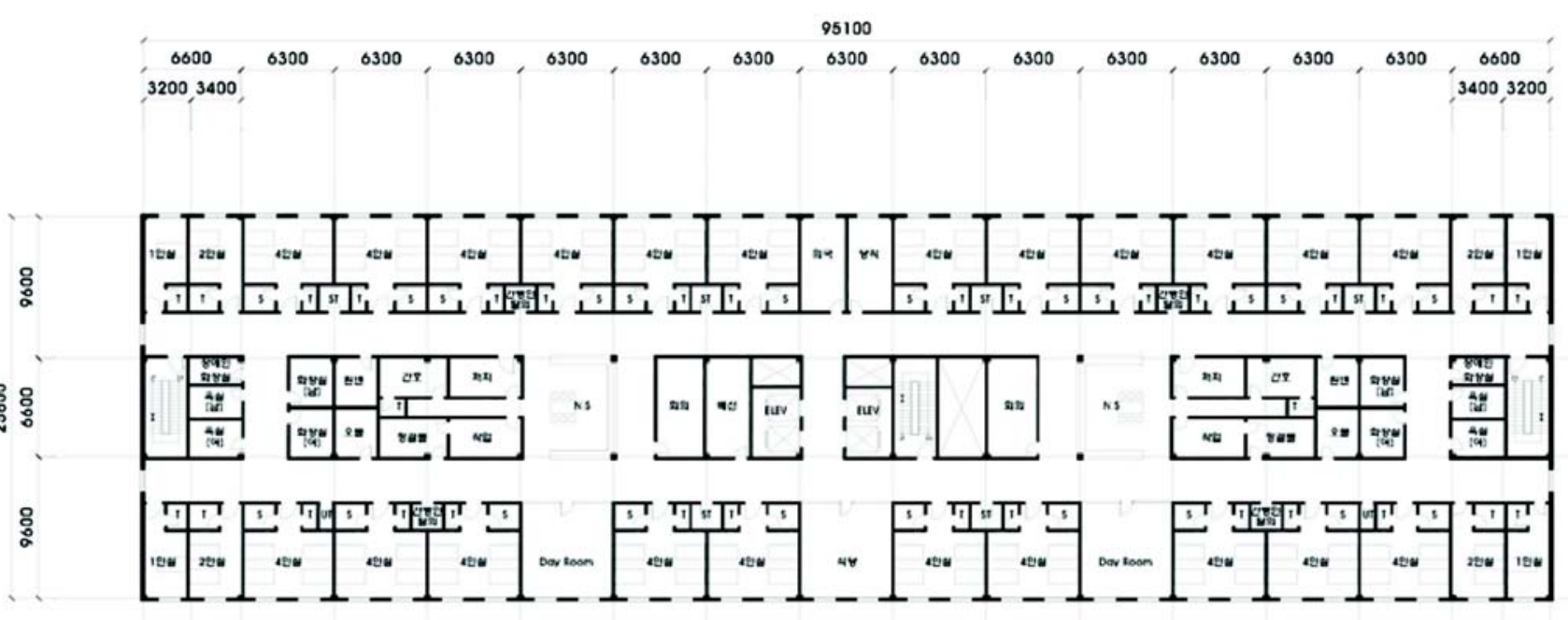

[그림 8] 이중복도형 병동 예시안 
Acknowledgements: this work was supported by the research fund of Division of Public Healthcare, Ministry of Health and Welfare in 2013.

\section{References}

권순정, 주소현, 2011.11, 종합병원의 병동부 기능공간 구성비율에 관한 연구, 한국의료복지시설학회지 17권 4호, 한국의료복지시설학회. 권오영, 양내원, 우리나라 종합병원 병동부의 최소기준 설정을 위한 건 축계획적 연구, 한국병원건축학회지, 제4권 4호, 1998. 12. PP 67 74.

김길채, 지방공사 의료원의 면적구성에 관한 건축계획적 연구, 한국병 원건축학회지, 제14권 2호, 2008. 5. PP 35 42.

김길채, 최광석, 병동부 평면유형에 관한 건축계획적 연구, 한국병원건 축학회지, 제6권 2호, 2000. 6. PP 59 65.

김만영, 양내원, 종합병원 병동부의 공공공간에 관한 건축계획적 연구, 한국병원건축학회지, 제6권 2호, 2000. 6. PP 15 21.

박남규, 양내원, 환자중심적 개념에 따른 병동부의 건축계획에 관한 이 론적 연구, 한국병원건축학회지, 제2권 2호, 1996. 7. PP 63 72.

박혁수, 박남규, 양내원, 환자중심적 병동부의 거주후 평가에 관한 건축 계획적 연구, 한국병원건축학회지, 제2권 3호, 1996. 12. PP 63 69. 보건복지부, 2012.7, 2013년 지역거점공공병원 기능보강 국고지원사업 지침.

보건복지부, 한국의료복지건축학회, 지역거점 공공병원 병동부 건축계 획 기준개발, 2013.5.

윤동현, 김길채, 김광문, 종합병원 병동부 간호관계제실에 관한 건축계 획적 연구, 한국병원건축학회지, 제1권 1호, 1995. 12. PP 43 51.

이상윤, 김화준, 의료서비스 질 향상을 위한 병원 인력 구조 개선 방안 - 간호 인력을 중심으로, 2008. 12.

정태우, 김광문, 병원 병동부 간호운영방식과 환자생활상에 따른 건축 계획적 연구, 한국병원건축학회지, 제1권 1호, 1995. 12. PP 7 20. 채철균, 최광석, 권순정, 공공병원 4인병실 유니트의 건축계획에 관한 연구, 의료·복지건축, 2013.8, PP.41 52.

한국보건산업진흥원, 2006.11 , 지방의료원 등 지역거점 공공병원의 공 공성 및 운영효율성 강화방안 연구

한국보건산업진흥원, 2013.3, 의료기관 입원환경 현황분석 보고서

Christine Nickl-Weller, Hans Nickl, 2006, The New Hospital, Page One Publishing Private Limited

Christoph Schirmer, Philipp Meuser, 2006, Hospital Architecture: General Hopitals and Health Centres

Facility Guidelines Institute, 2010, Guidelines for Design and Construction of Healthcare Facilities

Gesetz- und Verordnungsblatt fuer Berlin, 2006, Germany

Philipp Meuser, Christoph Schirmer, 2006, Neue Krankenhausbauten in Deutschland, DOM Publishers

접수 : 2013년 12월 30일 1차 심사 완료 : 2014년 01월 17일 게재확정일자 : 2014년 01월 17일 3인 익명 심사 필 